Article

\title{
The Relevance of Language as a Predictor of the Will for Independence in Catalonia in 1996 and 2020
}

\author{
Jordi Argelaguet \\ Department of Political Science and Public Law, Universitat Autònoma de Barcelona, Spain; \\ E-Mail: jordi.argelaguet@uab.cat
}

Submitted: 18 May 2021 | Accepted: 11 August 2021 | Published: 10 December 2021

\begin{abstract}
The Catalan secessionist parties, if added together, have won all the elections to the Parliament of Catalonia from 2010 to 2021. Their voters have been increasingly mobilized since the start of the controversial reform process of the Statute of Autonomy (2004-2010). The aim of this article is twofold. First, it intends to test whether language is the strongest predictor in preferring independence in two separate and distinct moments, 1996 and 2020. And second, to assess whether its strength has changed-and how-between both years. Only the most exogenous variables to the dependent variable are used in each of two logistic regressions to avoid problems of endogeneity: sex, age, size of town of residence, place of birth of the individual and of their parents, first language (L1), and educational level. Among them, L1 was-and still is-the most powerful predictor, although it is not entirely determinative. The secessionist movement not only gathers a plurality of Catalan native speakers, but it receives a not insignificant level of support among those who have Spanish as their L1. Conversely, the unionist group, despite being composed primarily by people who have Spanish as their L1 and have their family origins outside Catalonia, has a native Catalan-speaking minority inside. This imperfect division, which is based on ethnolinguistic alignments-and whose relevance cannot be neglected-alleviates the likelihood of an ethnic-based conflict.
\end{abstract}

\section{Keywords}

Catalonia; effective number of language groups; independence; language; logistic regression; secessionism; subjective national identity

\section{Issue}

This article is part of the issue "Secessionism in Liberal Democracies: What Do We Really Know About the Explanations of Secessionism?" edited by Ferran Requejo (Pompeu Fabra University, Spain) and Marc Sanjaume-Calvet (Pompeu Fabra University, Spain / Open University of Catalonia, Spain).

(C) 2021 by the author; licensee Cogitatio (Lisbon, Portugal). This article is licensed under a Creative Commons Attribution 4.0 International License (CC BY).

\section{Introduction}

Secessionism, since the first successful declaration of independence was signed in 1776 , is present in the political reality worldwide. Indeed, between 1945 and 2011, an average of 52 active secessionist movements per year has been identified (Griffiths, 2015). In parallel, there are two major approaches to analyse them: comparative studies and case studies. The latter is the option taken here, with the intention of bringing some clues to understand the growth of secessionism in Catalonia in recent years.

The Catalan case has received some attention because it is a secessionist process within a consolidated democracy, and within a relatively heterogeneous society, in linguistic and cultural terms. This heterogeneity is the result of several waves of immigration over the last decades. As a result, $36.4 \%$ of the population living in Catalonia were born outside of Catalonia (Institut d'Estadística de Catalunya, 2020). In this context, the Catalan language, a traditional marker of "Catalanness," went from being the first language (L1) of the vast majority of the Catalan population in 1900 (de Rosselló Peralta et al., 2020), to becoming L1 of only $31.5 \%$ of the population. Nonetheless, it is the reported language of identification of $43.2 \%$ of the population, while $94.4 \%$ say they understand Catalan and $81.2 \%$ can speak it (Institut d’Estadística de Catalunya, 2018). 
At the beginning of the democratic period in Spain, the percentage of secessionists was relatively low (in 1979 it was 8.6\%, according to Centro de Investigaciones Sociológicas [CIS], 1979). Between 1990 and 2010, it fluctuated around one-third of the population (see CIS, 1996, 2001; Institut de Ciències Polítiques i Socials [ICPS], 2020). From 2011 to the present, the percentage has been around 44\% (see Centre d'Estudis d'Opinió [CEO], 2021a, 2021b; ICPS, 2020). Therefore, in a few years, the growth of independence has been quite important, and it must be explained in the context of the political events that have taken place in Catalonia (Argelaguet, 2014; Casas et al., 2019; Colomines i Companys, 2020; Orriols \& Rodon, 2016; Rico \& Liñeira, 2014).

In this sense, the fact that the percentage of secessionists in Catalonia, either in the polls (about $44 \%$ ) or in the electoral results (in the 2021 elections, the combined pro-independence parties obtained $51 \%$ of the votes), is striking because it is higher than the percentage of people who have Catalan as their L1 (about 32\%) or even the percentage of those with Catalan as "language of identification" (43\%). This difference could be considered an outcome of the decision made by the main Catalan nationalist parties to promote a political discourse whose aim is to go beyond the perimeter of its core ethnic group, Catalan native speakers. The main leaders of the Catalan secessionist movement-Artur Mas, president of the Catalan government and Oriol Junqueras, president of the Republican Left of Catalonia (ERC; Argelaguet, 2011)-have underlined, for instance, that in an eventual independent Catalonia, the Catalan and the Spanish languages will be official languages (Barbeta, 2012; Junqueras, 2012). This compromise, however, generated a great debate within the ranks of the secessionist movement with hard-fought positions (Sendra, 2016), and links with the more academic debate on the scope of the civic component that has been historically detected in Catalan nationalism (Conversi, 1997; Keating, 1996; McRoberts, 2001). However, other authors have provided data that would seriously question this thesis (Álvarez-Gálvez et al., 2018; Miley, 2007).

The aim of this article is to check whether there has been a change over time in the role of the language in explaining the secessionist preferences that exist in Catalonia. The methodological option followed is to make a comparison of the data of two surveys conducted at two very different moments in time and in very different political contexts: 1996 and 2020. 1996 was the highest point of collaboration in the governance of Spain by the moderate Catalan nationalist force Convergència i Unió (CiU; Barrio \& Barberà, 2011). On the other hand, in 2020, secessionism had most seats in the Parliament of Catalonia.

For each year, I have used strictly the same model of a logistic regression, with the same variables, to see the elements of change and continuity, and whether the exacerbation of the conflict has produced changes in the internal composition based on linguistic groups of the two opposing poles: the secessionist and the non-secessionist. The variables used are the maximum possible exogenous to the dependent variable (the percentage of supporters of independence) to avoid problems of endogeneity or inverted causality: sex, age, size of town of residence, place of birth of the individual and of their parents, L1, and educational level.

Therefore, the proposed analysis allows increasing knowledge about a specific case that has aroused some interest in recent years, while providing data that will contrast the Catalan case with other cases and, perhaps, improve the knowledge that has been generated with their comparative analysis. The article will proceed as follows: In the next sections, I will present some theoretical considerations about the study of nationalism and secessionism. Then, I will present the data and methodology, show the results and address their discussion. I conclude by pointing out some clues to understand the framework through which the political debate in Catalonia can take place in the coming years.

\section{Theoretical Background}

The study of secessionism is linked to the study of nationalism. Inside the latter, there is a very relevant debate, propelled from the seminal work of Hans Kohn, about the existence of two types of nationalism, civic and ethnic (Kohn, 1944). The first one is based on the idea of inclusiveness, so that an individual's belonging to the nation is linked to voluntary elements, including adherence to legal norms. In contrast, the latter assumes that being a member of a nation is due to ascriptive elements, including ancestry, blood inheritance, or customs. This dichotomy, despite having been widely used, is criticized for being more normative than descriptive (Tamir, 2019) because its two components- "civic nationalism" and "ethnic nationalism" - are loaded terms and, moreover, "ethnic nationalism" is used pejoratively (Yacobson, 2013); others consider that is perhaps not a dichotomy but a continuum (Smith, 1991) because these are concepts with blurred borders that, in addition, are overburdened by usage, by the actors in the political conflict (Brubaker, 2004); in this case, this distinction-described as "Manichean" because one is good and the other bad-is "both normatively and analytically problematic" (Brubaker, 1998, p. 274).

Despite all this debate, this typology remains widely used in quantitative analysis, as is the case of the studies based on questions on national identity that have been included in the International Social Survey Program over several years. Using factor analysis, two dimensions have been identified from the answers given to the question of how important some elements are to define one's own national identity. The question is posed as follows in the questionnaire: "Some people say that the following things are important for being truly [nationality]. Others say they are not important. How important do you think each of the following is?", and the respondent was then 
asked about the importance of: (a) having been born in country X; (b) having country X's citizenship; (c) having lived in country $X$ for most of one's life; $(d)$ being able to speak country X's language; (e) being of a certain dominant religion; $(f)$ respecting country $X$ 's nationality, political institutions, and laws; and ( $g$ ) feeling a certain nationality (International Social Survey Program, 2015).

This empirical approach raises some problematic issues: There is a great diversity of interpretations of data (Jayet, 2012); there are discrepancies about how to label the dimensions that were found; and there is no same constant classification for all countries of the seven items in their respective dimensions. Moreover, there is a quite important level of association among all the items that can blur the dimensions. Nonetheless, items that include "to be born," "to have country's citizenship," "to have lived," and "religion" are usually linked to an ethnic dimension; and items "language," "to respect political institutions," and "to feel" link back to a civic dimension (Larsen, 2017). In addition, however, some items are not easily attributable to the "civic" or "ethnic" dimension, as is the case of "language," "an element of ethnic nationalism (a heritage of a culture) and, at the same time, it belongs to civic nationalism as an instrument of communication and of the participation in political institutions" (Jayet, 2012, p. 72). This debate is also present in the Catalan case (Álvarez-Gálvez et al., 2018). On the one hand, the Catalan language is the most obvious ethnic cultural marker of Catalan identity but, on the other hand, the language can be learned and become a source of social integration so that language barriers become permeable, which means that the language can be clearly distinguished from other ascriptive attributes, such as familial descent (Miley, 2007).

When the object of study becomes more focused on the analysis of secessionism, the initial point of reference is the seminal contribution of Donald L. Horowitz, who argues that the secessionism is explained in the framework of the intersection of ethnic identity and the socio-economic development of the groups involved. In poorer regions, through elites who exploit the resentment of the masses, secessionist ideologies are more likely to develop (Horowitz, 1985). At the same time, he shows that the relationship between ethnic diversity and severe ethnic conflict is nonmonotonic, with less violence for highly homogeneous and highly heterogeneous countries.

From here, the analysis of secessionism is devoted to answering several questions: Which are the factors that activate secessionism-once it is assessed that the cultural identity is very important but it is not determinant (Sorens, 2005) - given that there is a widespread range of competing hypotheses revolving around economic, cultural, and political factors? Does decentralization-and if so, under what circumstances-calm or ignite secessionism (Brancati, 2006)? Is secessionism (or, more broadly, ethnolinguistic mobilization) associated with violence (Brubaker \& Laitin, 1998)? Is language conflict a pre- scription for violence, or rather can language conflict, "under certain potentially incendiary conditions...help to contain violence" (Laitin, 2000, p. 98)? Finally, does the probability of conflict depend on ethnic diversity, as measured by the index of ethnic fractionalization (ELF). Despite it being widely used, the ELF receives some criticism: It is difficult to count all the groups, and it does not take into account the cultural distance among groups (Fearon, 2003), its historical evolution (Drazanova, 2020), or the polarization between them (Esteban et al., 2012).

However, with the intention of overcoming the shortcomings of the analyses compared to a very large $\mathrm{N}$, it may be convenient to resort to case studies to test general propositions in more detailed contexts and explore what are the elements that explain the growth of secessionism as, for instance, the present case of Catalonia.

In the Catalan case, like in other cases, secessionism can be analysed with electoral and other sociodemographic aggregated data or using opinion polls. With survey data, one can identify the strong predictors for independence, among them there is the national identification of the individual, also commonly referred to as subjective national identity (SNI). Because this variable is widely present in most of the analysis, it is helpful to clarify the problems associated with its use.

The SNI is operationalized through the so-called "Linz-Moreno question" (Moreno, 2006), which, despite its great academic use, has some problems: It does not adequately capture the identity intensity or linearity with national feelings and collects the existence of a large, too heterogeneous intermediate group (Guinjoan \& Rodon, 2016). In addition, the Catalan case has the problem of multiple meanings of the terms "Spanish" and "Catalan" (both can have a national or administrative meaning); and that of not being formulated in an excluding way (Cussó et al., 2018). However, the use of this scale is very common and has generated a large amount of data that allows comparative analysis in space and time.

The SNI in Catalonia has changed over the years. These changes have been more important between 1991 and 2006 than between 2010 and 2020, the years of the acceleration of the bid for independence (Table 1 ).

To explain the SNI, several aspects of the socialization process have to be considered: family (Rico \& Jennings, 2012), school (Clots-Figueras \& Masella, 2013), media (Hierro, 2010; Oller et al., 2019), government action (Martínez-Herrera, 2002). However, their impacts depend on the socio-demographic environment of each person (Barceló, 2014; Rodon \& Guinjoan, 2018).

Moreover, Serrano (2013) has proposed going beyond the sociodemographic factors that are given by birth, emphasizing the intervention of other relevant variables linked to nation-building policies, associated with changes in the institutional context that resulted from devolution arrangements, as the independent effect of media consumption in Catalan or, even, the support for fiscal autonomy. Despite all these elements, L1 is the key predictor for explaining SNI and, by 
Table 1. Evolution of the subjective national identity in Catalonia (1991-2020).

\begin{tabular}{lrrrrrrr}
\hline & 1991 & 1996 & 2006 & 2010 & 2011 & 2020 \\
\hline Only Spanish + More Spanish than Catalan & 17.4 & 24.4 & 10.8 & 9.4 & 9.0 & 10.1 \\
Equally Spanish as Catalan & 46.7 & 36.5 & 44.3 & 42.5 & 42.8 & 39.2 \\
Only Catalan + More Catalan than Spanish & 35.3 & 36.7 & 41.7 & 45.8 & 46.4 & 44.7 \\
DK/DA & 0.6 & 2.4 & 3.2 & 2.3 & 1.8 & 6.0 \\
$\mathrm{~N}$ & 1.972 & 797 & 2.000 & 2.000 & 2.500 & 6.000 \\
\cline { 2 - 7 } & ICPS & CIS 2228 & CEO 367 & CEO 612 & CEO 652 & CEO 2020 \\
\hline
\end{tabular}

Notes: The usual five categories have been collapsed into three; ${ }^{1}$ In 2020, it is the merger of the CEO's three surveys: No. 962, no. 974 , and no. 985. Sources: CEO (2006, 2010, 2011, 2020a, 2020b, 2020c), CIS (1996), ICPS (1991).

extension, the preference for independence (Chernyha \& Burg, 2012).

Therefore, even though it is a verified fact that the older generations have been replaced by more proindependence generations (Bartomeus, 2018), the significant increase in secessionism from 2010 onward would not be explained by the small changes in the SNI. For this reason, other complementary hypotheses have been raised, such as risk aversion by gender (Verge et al., 2015), or, above all, that the growth of secessionism would have been driven by political elites in an outbidding process (Barrio \& Rodríguez-Teruel, 2017). As an alternative to this top-down hypothesis, others raise the bottom-up one, that is, there would have been a very intense pro-secession popular mobilization that, through large demonstrations or holding popular consultations (Muñoz \& Guinjoan, 2013), would have pushed the parties, from 2008, to act in favour of independence (Dowling, 2014).

Without being able to ignore the weight of the SNI, other analyses have focused on fiscal policy preferences (Boylan, 2015), on individual exposure to the effects of the global economy (Hierro \& Queralt, 2020), and on the concurrence of instrumental and welfare maximizing reasons (Muñoz \& Tormos, 2015). However, with aggregate or individual level data, others state that there would be no relationship between crisis and the rise of secessionism (Bel et al., 2019; Cuadras-Morató \& Rodon, 2019), or find that the pro-independence vote in 2017 is more tied to individuals' place of birth and that, in contrast, typically economic predictors (GDP per capita, poverty level, or unemployment level) are not relevant (Maza et al., 2019).

In conclusion, to explain secessionism in Catalonia, instead of re-including the SNI due to measurement and endogeneity problems with the dependent variable (Tormos et al., 2015), I will use the variables that are as exogenous as possible to it: L1, individual's place of birth and their parents' place of birth, gender, age, size of town of residence, and level of education. It has been ruled out to include the ideological variable, measured through self-location on the left-right axis, because in Catalonia it carries an endogenous component linked to the national question (Dinas, 2012).
In consequence of the previous exposition, the hypotheses that are going to be tested are the following ones:

$\mathrm{H1}$ : Language is one of the basic features defining an ethnic group (Fishman, 1999, p. 4); it is able to generate a nationalist movement and even propose a secessionist project; is the most relevant predictor of the socio-demographic variables considered. So, in the case of Catalonia, and in both years under analysis, those citizens with Catalan as their L1 will have more probabilities of being in favour of independence than those citizens whose L1 is Spanish.

$\mathrm{H} 2$ : Given that it is well established that the escalation of a national conflict-like one related to independence-may lead to a growing social divide alongside language groups, it is expected that the weight of language as a predictor of secessionism in any person will increase its importance if the context becomes politically agitated. So, in the case of Catalonia, between 1996 and 2020, the likelihood of wanting independence if the $\mathrm{L} 1$ of this person is Catalan (in contrast to if their L1 is Spanish) will increase. Specifically, it should be noted that the growth of secessionism will be proportionally stronger among Catalans with Catalan as their L1 than among the rest of the people. If this happens, it will be evidence that the independence process would have reinforced the social division based on the linguistic alignment of individuals.

H3: The growing warming of the political debate in a context where the language factor is relevant must imply that each language group will be progressively aligned with each option (Catalan native speakers with independence and Spanish native speakers with non-independence). The outcome will be that in both blocs - for and against independencetheir language diversity will be reduced, measured by applying the formula for effective number of parties to calculate the effective number of language 
groups (ENLG). In this sense, ENLG $=1 / \sum_{i=1}^{n} p_{i}^{2}$, within a society or a group of people containing several language groups, where $p_{i}$ is the language group proportion in the society (or other grouping), according to their L1.

However, because in the case of Catalonia there is enough evidence that the secessionist movement has intended to avoid the risk of social division by underlining that the current linguistic rights of all will not be changed in an eventual Catalan republic (where Catalan and Spanish will be official languages), it will be expected that this homogenization will not only not grow within the secessionist bloc, but, instead, its internal diversity in language groups will increase. This fact could be interpreted as a relatively successful result for the proindependence movement of having appealed in its political discourse to elements contrary to the division of society by language alignments.

\section{Data and Methodology}

The data for this analysis comes from two face-to-face surveys. One is the 1996 Study 2228 of the CIS. The second is the merger of the three waves of the 2020 Political Opinion Barometer of the CEO. Despite CIS depending on the Spanish government and CEO on the Catalan one, there is no evidence of substantial bias in their data. They both follow rigorous validation mechanisms of the methodology for obtaining the data, which are widely used by the academic community thanks to their policies of transparency. Moreover, at CEO, the samples are designed considering cross-quotas of gender, age, and place of birth.

The dependent variable is the opinion regarding the independence of Catalonia, and it has been dichotomized (Table 2).

The independent variables included in the logistic regressions are as exogenous as possible to the dependent variable, so that the sense of causality was unidirectional and endogeneity problems were avoided. The vari- ables are sex, age, size of town, individuals' place of birth, parents' place of birth, L1, and level of education. L1 is a trait on which the individual has no capacity for choice, and it is prior to the self-conscious formulation of one's own identity. As for the level of education achieved, despite being the result of a set of diverse factors, I have incorporated it into the analysis because lacking an appropriate measure of social class or socioeconomic status, education could be used as a proxy predictor of social economic status. The frequencies of these variables and their cross tabulation with the dependent variable are shown in Table $1 \mathrm{~A}$ in the Supplementary File. In this table, two variables have been added, although they are not used in the analysis.

In the next section, I will show the results of the two logistic regressions. The same model has been used to compare the data in 1996 with that of 2020. In the independent variables, the base group is always the first category listed.

\section{Results and Discussion}

The two regressions return similar results in terms of the direction of the association between the categories of the independent variables and the dependent variable, except for sex and age group. Statistical significance is higher in the 2020 data. Pseudo- $R^{2}$ (0.280 in 1996 and 0.321 in 2020) and correctly classified cases $(74.8 \%$ in 1996 and $73.8 \%$ in 2020) are similar (Table 3).

To clearly show the main findings, in Table 3 there are the odds ratios (the $\operatorname{Exp}(B)$ of both regressions) and their equivalence in probabilities of wanting independence in relationship to the base group (the first category in each variable).

Gender is associated differently in both years. While in 1996, being male reduces the chances of agreeing with independence, in 2020 it is the other way around and, in addition, it is with minimal statistical significance. It could be explained by the combination of the possible likelihood of the proximity of independence with risk aversion, more present among women.

Table 2. Opinion about the independence of Catalonia (1996 and 2020).

\begin{tabular}{lccc}
\hline & 1996 (CIS 2228, N = 747) & & 2020 (CEO, N = 6.000) \\
\cline { 2 - 3 } & $\begin{array}{l}\text { Personally, would you be in favour or against } \\
\text { that Catalonia was independent? }\end{array}$ & & $\begin{array}{c}\text { Do you want Catalonia to become an } \\
\text { independent State? }\end{array}$ \\
\hline In favour/yes & 33.2 & 43.5 \\
Against/no & 52.9 & 48.9 \\
DK & 10.7 & 5.9 \\
DA & 2.1. & 1.7 \\
Missing & 1.1. & \\
Total & 100 & 100 \\
Independence? & 33.2 (In favour) & 43.5 (Yes) \\
& 68.8 (All other answers) & 56.5 (All other answers)
\end{tabular}

Note: In 2020, it is the merger of the CEO's studies no. 962, no. 974, and no. 985. Sources: CIS (1996), CEO (2020a, 2020b, 2020c). 
Table 3. Logistic regressions (1996 and 2020).

\begin{tabular}{|c|c|c|c|c|c|c|c|c|c|c|}
\hline & \multicolumn{5}{|c|}{1996} & \multicolumn{5}{|c|}{2020} \\
\hline & & & & & $\%$ & & & & & $\%$ \\
\hline & B & St.Err & sig & $\operatorname{Exp}(B)$ & probability & B & St.Err. & sig & $\operatorname{Exp}(B)$ & probability \\
\hline \multicolumn{11}{|l|}{ Sex } \\
\hline \multicolumn{11}{|l|}{ Female } \\
\hline Male & -0.046 & 0.180 & & 0.955 & 48.85 & 0.102 & 0.061 & $*$ & 1.108 & 52.56 \\
\hline \multicolumn{11}{|l|}{ Age group } \\
\hline \multicolumn{11}{|l|}{$18-24$ years } \\
\hline $25-34$ & -0.086 & 0.294 & & 0.918 & 47.86 & 0.117 & 0.136 & & 1.124 & 52.92 \\
\hline $35-44$ & 0.064 & 0.319 & & 1.066 & 51.60 & 0.312 & 0.128 & $* *$ & 1.366 & 57.73 \\
\hline $45-54$ & 0.427 & 0.356 & & 1.533 & 60.52 & 0.578 & 0.128 & $* * *$ & 1.783 & 64.07 \\
\hline $55-64$ & 0.070 & 0.381 & & 1.072 & 51.74 & 0.732 & 0.133 & $* * *$ & 2.078 & 67.51 \\
\hline $65-74$ & -0.197 & 0.404 & & 0.821 & 45.09 & 0.525 & 0.137 & $* * *$ & 1.691 & 62.84 \\
\hline$>74$ years & -0.897 & 0.521 & $*$ & 0.408 & 28.98 & 0.561 & 0.158 & $* * *$ & 1.752 & 63.66 \\
\hline \multicolumn{11}{|l|}{ Size of town } \\
\hline \multicolumn{11}{|l|}{ Less than 2.001} \\
\hline $2.001-10.000$ & -0.116 & 0.383 & & 0.891 & 47.12 & -0.287 & 0.163 & $*$ & 0.751 & 42.89 \\
\hline $10.001-50.000$ & -0.281 & 0.368 & & 0.755 & 43.02 & -0.422 & 0.154 & $* * *$ & 0.656 & 39.61 \\
\hline $50.001-150.000^{1}$ & -0.025 & 0.422 & & 0.975 & 49.37 & -0.865 & 0.160 & $* * *$ & 0.421 & 29.63 \\
\hline $150.001-400.000^{1}$ & -0.372 & 0.385 & & 0.689 & 40.79 & -0.698 & 0.169 & $* * *$ & 0.497 & 33.20 \\
\hline Barcelona & -0.098 & 0.358 & & 0.907 & 47.56 & -0.722 & 0.159 & $* * *$ & 0.486 & 32.71 \\
\hline \multicolumn{11}{|l|}{ Birth } \\
\hline \multicolumn{11}{|l|}{ Other answers } \\
\hline Born in Catalonia & 0.679 & 0.292 & $* *$ & 1.972 & 66.35 & 0.570 & 0.090 & $* * *$ & 1.768 & 63.87 \\
\hline \multicolumn{11}{|l|}{ Parents' origins } \\
\hline \multicolumn{11}{|l|}{$\begin{array}{l}\text { Both parents out } \\
\text { of Catalonia }\end{array}$} \\
\hline One parent in Cat. & 0.465 & 0.337 & & 1.593 & 61.43 & 0.332 & 0.097 & $* * *$ & 1.394 & 58.23 \\
\hline Both born in Cat. & 0.526 & 0.321 & & 1.691 & 62.84 & 0.619 & 0.105 & $* * *$ & 1.857 & 65.00 \\
\hline \multicolumn{11}{|l|}{ L1 } \\
\hline \multicolumn{11}{|l|}{ Spanish } \\
\hline Both Cat. \& Spa. & 0.859 & 0.583 & & 2.360 & 70.24 & 0.555 & 0.149 & $* * *$ & 1.742 & 63.53 \\
\hline Catalan & 1.206 & 0.285 & $* * *$ & 3.341 & 76.96 & 1.360 & 0.089 & $* * *$ & 3.898 & 79.58 \\
\hline Other answer & 0.294 & 0.609 & & 1.342 & 57.30 & 0.569 & 0.174 & $* * *$ & 1.767 & 63.86 \\
\hline DK/DA & 2.389 & 1.259 & $*$ & 10.905 & 91.60 & 0.710 & 0.618 & & 2.035 & 67.05 \\
\hline \multicolumn{11}{|l|}{ Education } \\
\hline \multicolumn{11}{|l|}{ Less than primary } \\
\hline Primary & 0.133 & 0.276 & & 1.143 & 53.34 & 0.301 & 0.113 & $* * *$ & 1.352 & 57.48 \\
\hline Secondary & 0.156 & 0.319 & & 1.169 & 53.90 & 0.625 & 0.116 & $* * *$ & 1.868 & 65.13 \\
\hline Superior & 0.591 & 0.331 & $*$ & 1.806 & 64.36 & 0.807 & 0.119 & $* * *$ & 2.242 & 69.15 \\
\hline DK/DA \& other & 0.807 & 1.027 & & 2.240 & 69.14 & 0.198 & 0.676 & & 1.218 & 54.91 \\
\hline Constant & -2.018 & 0.510 & $* * *$ & 0.133 & & -1.954 & 0.216 & $* * *$ & 0.142 & 52.56 \\
\hline $\mathrm{N}$ & 747 & & & & & 6000 & & & & \\
\hline Log likelihood 2 & 781.503 & & & & & 6576.100 & & & & \\
\hline Nagelkerke $\mathrm{R}^{2}$ & 0.280 & & & & & 0.321 & & & & \\
\hline Correct \% & 74.8 & & & & & 73.8 & & & & \\
\hline Chi-squared & 168.057 & & & & & 1640.501 & & & & \\
\hline $\mathrm{df}$ & 23 & & & & & 23 & & & & \\
\hline$p$-value & 0.000 & & & & & 0.000 & & & & \\
\hline
\end{tabular}

Notes: ${ }^{1} \operatorname{In} 1996,50.001-100.000 ; 100.001-400.000 ;{ }^{*} p<0.1{ }^{* *} \mathrm{p}<0.05 ; * * *<0.01$; dependent variable is the desire for independence; percentage of probabilities: $\operatorname{Exp}(B) /(1+\operatorname{Exp}(B)) \times 100$. 
As for the age group, in 1996, the chances of agreeing with independence increase in some categories with respect to the base group, but in others they decrease, as in the case of those over 74 , the only one with statistical significance. It could be a generational effect: The individuals in this group were of military age during the Spanish Civil War. By 2020, the chances of wanting independence increase in all categories compared to the base group. The fact that this group, of those who have lived through the independence process in their teens, has the lowest percentage of secessionists of all, and the fact that the group of 55 to 64 year olds has the highest percentage of secessionists, would nuance the alleged role that has been played in the process of socialization by the media and the education system under the responsibility of the Government of Catalonia-which is in the hands of Catalan nationalists (Miley \& Garvía, 2019; Tobeña, 2017). In any case, an analysis of the effects of age, cohort, and period on the will to independence, and considering the main effect of primary socialization will be needed. Thus, in 1996, among young people aged 18-24 and with Spanish as L1, those who agreed with independence were part of the $20.3 \%$. In this same subgroup, in 2020 , the pro-independence individuals are $20.7 \%$. But, among young people aged 18-24 and with Catalan as $L 1$, those who agreed with independence are part of the $54.8 \%$. In this same subgroup, in 2020 , the proindependence individuals are $67.2 \%$.

The size of the town of residence is also associated with the will for independence in both years, although with different statistical significance. The larger the town is, the lower the chances of wanting independence compared to the base group are (the smaller towns). This circumstance is linked to the presence of more inhabitants from Spanish immigration in the big cities, most of them surrounding Barcelona, and in Barcelona itself.

Being born in Catalonia significantly increases the likelihood of agreeing or wanting independence. However, probabilities are slightly reduced in 2020. There is also an incremental positive effect when the individual's parents are both born in Catalonia (or at least one parent), compared to those who do not have any parent born in Catalonia. Therefore, the idea that primary socialization becomes a relevant factor as a predictor of secessionism is reinforced. However, secessionism has not grown evenly in both groups. Between 1996 and 2020, in the group of both parents born outside Catalonia, secessionism has gone from $16.2 \%$ to $23.3 \%$, an increase of $43.8 \%$. And in the group of those who have both parents born in Catalonia, secessionism has gone from $55.8 \%$ to $68.6 \%$, a $22.9 \%$ increase.

This data confirms confirm that the most important predictor is L1. If one has Catalan as L1 is much more likely to want independence than if $\mathrm{L} 1$ is Spanish. However, the growth of secessionism has been uneven depending on the L1. Among those who have Spanish as L1, percentage has gone from $16.3 \%$ in 1996 to $24.6 \%$ in 2020 , an increase of $50.9 \%$. And among those who have Catalan as $\mathrm{L} 1$, secessionism has gone from $56.4 \%$ to $73.4 \%, 17$ points, and an increase of $30.1 \%$ (Table A1 in the Supplementary File).

Because the marginal effects provide information on which factors contribute most to explaining the dependent variable, the average marginal effects of the exploratory variables are visualized in Figure 1 for ease of interpretation. I show the likelihood of independence given values on the explanatory variables, while holding all other variables at their means.

In 1996, in terms of average marginal effects, the probability of being in favour of independence is the greatest when the L1 is Catalan (23.9\%), followed by when the respondent is born in Catalonia (12\%) and when they have a high level of formal education (10.6\%). On the contrary, when the respondent is older than 74 years, the likelihood decreases (14\%).

In 2020, the likelihood of wanting independence is greatest when, again, the respondent's L1 is Catalan $(29.6 \%)$, when their level of formal education is the highest $(14.9 \%)$, when they are 55-64 years old (13.2\%), when their parents are both born in Catalonia (12.3\%), and when they born in Catalonia (10.8\%). On the contrary, the likelihood of preferring independence is lowest when the town they are living in has between 50.000 and 150.000 inhabitants (16.3\%).

In summary, to have the Catalan language as L1 has the largest effect on preferring independence in both years. However, it must be underlined that in both models where it is included, they only correctly classify $73-75 \%$ of cases (see Table 3). Therefore, it means that the rest of the cases (about 25\%) should be classified with the concurrence of other variables not included in the model.

A more descriptive approach is useful to complete this analysis. With reference to Table A1 (Supplementary File), in 2020, the profile of the unionists is as follows: $43.9 \%$ were born outside Catalonia; $64.2 \%$ have both parents also born outside Catalonia; $75.3 \%$ have Spanish as L1; $49 \%$ have an educational level up to primary; and $24.1 \%$ have higher education. In addition, $71.9 \%$ have no grandparents born in Catalonia. The profile of secessionists is this: $85.8 \%$ were born in Catalonia; $55 \%$ have both parents born in Catalonia; $61.7 \%$ have Catalan as L1; $32.6 \%$ have primary educational level; and $36.3 \%$ have university level. In addition, $35.4 \%$ have four grandparents born in Catalonia.

From the crosstabulation of the L1 by the will for independence in 1996 and 2020 (in columns), the ENLG for the whole of Catalonia and for the pro-independence and unionist subgroups are calculated (Table 4).

In 1996, the ENLG for Catalonia was 2.15. For the unionist subgroup, it was 1.83 and for the secessionist one, it was 1.88 . Both groups were very similar in homogeneity, while they seemed to confront each other like a mirror: more than $2 / 3$ in the dominant group and $1 / 3$ in the minority group, respectively.

In 2020, the ENLG for Catalonia was 2.20. The ENLG for the unionist subgroup fell to 1.67 . On the other hand, 

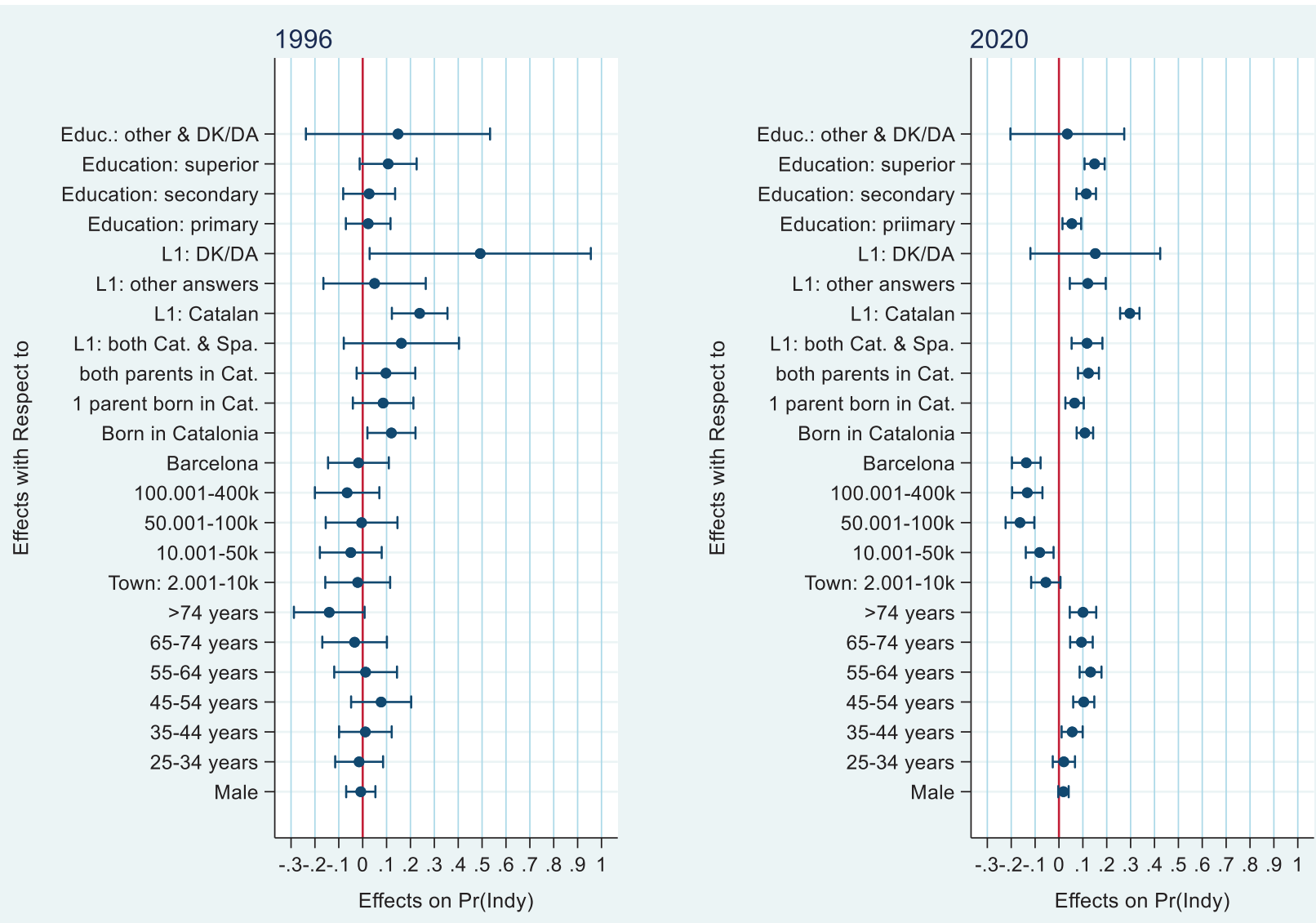

Figure 1. Probabilities of preferring independence. Note: Average marginal effects with 95\%. Sources: CIS (1996), CEO (2020a, 2020b, 2020c).

the ENLG for the pro-independence subgroup rose to 2.06. Therefore, while unionism has become more homogeneous with the increase in the percentage of those who have Spanish as their L1, secessionism has become more heterogeneous because it has also penetrated this part of the population.

This double dynamic may show the results of the political strategy followed by the leaders of both blocks. It has been tested that Catalan political parties generally do not use the main identity marker in Catalonia (language) for outbidding purposes and, if they do, it is the unionist parties that resort to it more than the pro-independence parties (Sanjaume-Calvet \& Riera-Gil, 2020). In this sense, in recent years, the unionists have increasingly used Spanish in the Parliament of Catalonia; and most pro-independence parties have incorporated some leaders who do not have Catalan as L1.

The growth of secessionism cannot be explained without taking into consideration that the secessionist leadership has promoted a political discourse that it is trying to become rooted in a civic use of the question of language, i.e., the desirability of the Catalan

Table 4. Effective number of language groups in Catalonia (1996 and 2020).

\begin{tabular}{|c|c|c|c|c|c|c|c|}
\hline & & \multicolumn{3}{|c|}{1996} & \multicolumn{3}{|c|}{2020} \\
\hline & & \multicolumn{3}{|c|}{ Are you in favour or against independence? } & \multicolumn{3}{|c|}{ Do you want the independence? } \\
\hline & & Total & In favour & other & Total & yes & other \\
\hline \multirow[t]{5}{*}{ L1 } & Spanish & 55.2 & 27.0 & 69.1 & 56.4 & 31.9 & 75.3 \\
\hline & Both languages & 2.0 & 2.8 & 1.6 & 3.8 & 4.1 & 3.5 \\
\hline & Catalan & 39.9 & 67.7 & 26.1 & 36.6 & 61.7 & 17.2 \\
\hline & Other answers & 2.5 & 1.6 & 3.0 & 3.1 & 2.1 & 3.8 \\
\hline & DK/DA & 0.4 & 0.8 & 0.2 & 0.2 & 0.2 & 0.2 \\
\hline Total & & 100.0 & 100.0 & 100.0 & 100.0 & 100.0 & 100.0 \\
\hline ENLG & & 2.15 & 1.88 & 1.83 & 2.20 & 2.06 & 1.67 \\
\hline
\end{tabular}


language to become the shared language of the inhabitants of Catalonia, while respecting the language rights of the Spanish speakers, and assuming that in the future Catalan Republic, Catalan and Spanish will have the status of official languages. Without this strong commitment (although it is contested within its own ranks), the secessionist project could be at risk. Catalonia nowadays is a subordinate political community. The plurality of its citizens has family origins outside Catalonia (54.2\% of voters have no grandparents born in Catalonia; see Table A1). The L1 of the plurality of the Catalan electorate is Spanish (56.4\%; see Table A1). With these two sociodemographic traits, it is wise for the secessionist project to avoid an ethnic outbidding because it could alienate its supporters who are Spanish native speakers and, consequently, it could jeopardize the strength of the proindependence block.

\section{Conclusion}

In this article, I have used the same logistic regression model with some sociodemographic variables to explain probabilities in wanting independence in Catalonia in two quite different political contexts (1996 and 2020), with the aim to compare change and continuities between them, and to expose some political consequences.

In both years, L1 has been the strongest predictor of those considered. Second, the likelihood of wanting independence depending on whether one has Catalan as L1 compared to Spanish was $77 \%$ in 1996 and $80 \%$ in 2020, only a low increase of probability. Third, the growth of secessionism has been proportionally stronger among Catalans with Spanish as their L1 than among Catalans with Catalan as their L1. Given the impact of ethnolinguistic diversity on ethnic conflict, after calculating the ENLG for the whole of Catalonia and for the unionist and secessionist subgroups, I can assert that the unionist subgroup has become more homogeneous, while the pro-independence subgroup has become slightly more diverse. It shows that secessionism succeeds in attracting more different people, according to their language (or cultural) background.

These results are congruent with the proposition that despite language being a strong marker of ethnic identity, the language issue plays a lesser role within the whole conflict as could have been previously expected, as both blocks under political confrontation do not reflect strict language alignments.

Cross tabulating the variable $\mathrm{L} 1$ with the will of independence within the whole electorate, the weight of each resulting subgroup is calculated (Table 5 ). This procedure becomes relevant to realize what kind of political dynamics might occur in Catalonia.

The largest group within the Catalan electorate (37.9\%) is composed by those who have Spanish as L1 and do not want independence. The second larger one is those who have Catalan as L1 and want independence (26.9\%). The third group is those who have Spanish as L1 and want independence (13.9\%). The fourth one, with $9.7 \%$, is those who have Catalan as L1 and do not want independence. None of the remaining groups reached $4 \%$ of the sample. The third and fourth groups weaken the association between L1 and independence. Moreover, two more aspects have to be underlined relating to the third group: Its weight within Catalan society is not small (13.9\%) and its weight within the pro-independence group is quite big (31.9\%). In short, although Catalan independence has the support of a great majority of native Catalans, its relative success cannot be understood without the participation of Catalans whose family origins are outside Catalonia. The growth of secessionism this last decade must therefore be explained also by the ability of pro-independence leaders and organizations to make a discourse based on civicdemocratic arguments. These arguments have been quite effective in appealing to sectors with a Spanish cultural background and, consequently, to transcend the language borders that unionism could be tempted to consolidate.

\section{Acknowledgments}

The author would like to thank Raül Tormos for his support and helpful feedback on a previous version of the manuscript, and the anonymous reviewers for their insightful comments. The usual disclaimer applies.

\section{Conflict of Interests}

The author declares no conflict of interests.

Table 5. Crosstabulation L1 by independence (2020).

\begin{tabular}{|c|c|c|c|c|c|c|}
\hline \multirow[b]{2}{*}{ Overall \% } & & \multicolumn{5}{|c|}{ Do you want Catalonia to become an independent state? } \\
\hline & & Yes & No & DK & DA & Total \\
\hline \multirow{6}{*}{ L1 (L1) } & Spanish & 13.9 & 37.9 & 3.6 & 1.0 & 56.4 \\
\hline & Both languages & 1.8 & 1.7 & 0.3 & 0.0 & 3.8 \\
\hline & Catalan & 26.9 & 7.4 & 1.7 & 0.6 & 36.6 \\
\hline & Other languages & 0.9 & 1.8 & 0.3 & 0.1 & 3.1 \\
\hline & DK/DA & 0.1 & 0.1 & 0.0 & 0.0 & 0.2 \\
\hline & Total & 43.5 & 48.9 & 5.9 & 1.7 & 100.0 \\
\hline
\end{tabular}




\section{Supplementary Material}

Supplementary material for this article is available online in the format provided by the author (unedited).

\section{References}

Álvarez-Gálvez, J., Echavarren, J. M., \& Coller, X. (2018). Bound by blood: The ethnic and civic nature of collective identities in the Basque Country, Catalonia and Valencia. Nations and Nationalism, 24(2), 412-431. https://doi.org/10.1111/nana.12379

Argelaguet, J. (2011). Esquerra Republicana de Catalunya [Republican Left of Catalonia]. In A. Elias \& F. Tronconi (Eds.), From protest to power. Autonomist parties and the challenges of representation (pp. 147-169). Braumüller.

Argelaguet, J. (2014). From autonomism to independentism: The growth of secessionism in Catalonia (2010-2013). In J. Lluch (Ed.), Constitutionalism and the politics of accommodation in multinational democracies (pp. 108-131). Palgrave Macmillan. https://doi.org/10.1057/9781137288998

Barbeta, J. (2012, October 12). Entrevista Artur Mas Presidente de la Generalitat [Interview to Artur Mas President of the Catalan Government]. La Vanguardia, 10-12.

Barceló, J. (2014). Contextual effects on subjective national identity: Contextual effects on subjective national identity. Nations and Nationalism, 20(4), 701-720. https://doi.org/10.1111/nana.12080

Barrio, A., \& Barberà, O. (2011). Convergència i unió [Convergence and Union]. In A. Elias \& F. Tronconi (Eds.), From protest to power. Autonomist parties and the challenges of representation (pp. 75-98). Braumüller.

Barrio, A., \& Rodríguez-Teruel, J. (2017). Reducing the gap between leaders and voters? Elite polarization, outbidding competition, and the rise of secessionism in Catalonia. Ethnic and Racial Studies, 40(10), 1776-1794. https://doi.org/10.1080/01419870. 2016.1213400

Bartomeus, O. (2018). El terratrèmol silenciós. Relleu generacional $i$ transformació del comportament electoral a Catalunya [The silent earthquake. Generational change and transformation of the electoral behaviour in Catalonia]. Eumo. https:// lafinestralectora.cat/el-terratremol-silencios

Bel, G., Cuadras-Morató, X., \& Rodon, T. (2019). Crisis? What crisis? Economic recovery and support for independence in Catalonia. Regional Science Policy \& Practice, 11(5), 833-848. https://doi.org/10.1111/ rsp3.12236

Boylan, B. M. (2015). In pursuit of independence: The political economy of Catalonia's secessionist movement: In pursuit of independence. Nations and Nationalism, 21(4), 761-785. https://doi.org/ 10.1111/nana.12121
Brancati, D. (2006). Decentralization: Fueling the fire or dampening the flames of ethnic conflict and secessionism? International Organization, 60(3). https:// doi.org/10.1017/S002081830606019X

Brubaker, R. (1998). Myths and misconceptions in the study of nationalism. In J. A. Hall (Ed.), The state of the nation. Ernest Gellner and the theory of nationalism (pp. 272-306). Cambridge University Press.

Brubaker, R. (2004). Ethnicity without groups. Harvard University Press.

Brubaker, R., \& Laitin, D. D. (1998). Ethnic and nationalist violence. Annual Review of Sociology, 24(1), 423-452. https://doi.org/10.1146/annurev.soc.24.1.423

Casas, F. A., Etxearte, O., Martínez Amat, M., Mateos, R., Pruna, G., \& Tomàs, N. (2019). Tota la veritat. La crònica definitiva dels dies decisius del Procés [The whole truth. The definitive chronicle of the decisive days of the process]. Ara Llibres.

Centre d'Estudis d'Opinió. (2006). Baròmetre d'opinió política. 4a onada 2006 (Estudio no. 367) [Political opinion barometer. 4th wave 2006 (Study no. 367)] [Data set]. Centre d'Estudis d'Opinió. https://ceo. gencat.cat/ca/barometre/detall/index.html?id=506

Centre d'Estudis d'Opinió. (2010). Baròmetre d'opinió política. 4a onada 2010 (Estudio no. 612) [Political opinion barometer. 4th wave 2010 (Study no. 612)] [Data set]. Centre d'Estudis d'Opinió. https://ceo. gencat.cat/ca/barometre/detall/index.html?id=3068

Centre d'Estudis d'Opinió. (2011). Baròmetre d'opinió política. 2a onada 2011 (Estudio no. 652) [Political opinion barometer. 2nd wave 2011 (Study no. 652)] [Data set]. Centre d'Estudis d'Opinió. https://ceo. gencat.cat/ca/barometre/detall/index.html id $=3648$

Centre d'Estudis d'Opinió. (2020a). Baròmetre d'opinió política. 1a onada 2020 (Estudio no. 962) [Political opinion barometer. 1st wave 2020 (Study no. 962)] [Data set]. Centre d'Estudis d'Opinió. https://ceo. gencat.cat/ca/barometre/detall/index.html?id=7548

Centre d'Estudis d'Opinió. (2020b). Baròmetre d'opinió política. 2a onada 2020 (Estudio no. 974) [Political opinion barometer. 2nd wave 2020 (Study no. 974)] [Data set]. Centre d'Estudis d'Opinió. https://ceo. gencat.cat/ca/barometre/detall/index.html?id=7688

Centre d'Estudis d'Opinió. (2020c). Baròmetre d'opinió politica. 3a onada 2020 (Estudio no. 985) [Political opinion barometer. 3rd wave 2020 (Study no. 985)] [Data set]. Centre d'Estudis d'Opinió. https://ceo. gencat.cat/ca/barometre/detall/index.html?id=7808

Centre d'Estudis d'Opinió. (2021a). Matriu fusionada del Baròmetre. Matriu de dades fusionada fins al 2013 (telefònica) [Barometer's integrated data set until 2013 (CATI)] [Data set]. Centre d'Estudis. https://ceo.gencat.cat/ca/barometre/matriusfusionada-BOP

Centre d'Estudis d'Opinió. (2021b). Matriu fusionada del Baròmetre. Matriu de dades fusionada a partir de 2014 (presencial) [Barometer's integrated data set from 2014 (CAPI)] [Data set]. Centre d'Estudis 
d’Opinió. https://ceo.gencat.cat/ca/barometre/ matrius-fusionada-BOP

Centro de Investigaciones Sociológicas. (1979). Conciencia regional I/ (Estudio no. 1190) [Regional conscience II (Study no. 1990)] [Data set]. Centro de Investigaciones Sociológicas. https://www.cis.es/cis/ opencm/ES/1_encuestas/estudios/ver.jsp?estudio= $182 \&$ cuestionario $=224 \&$ muestra $=3851$

Centro de Investigaciones Sociológicas. (1996). Conciencia nacional y regional. Cataluña (Estudio no. 2228) [National and regional conscience. Catalonia (Study no. 2228)] [Data set]. Centro de Investigaciones Sociológicas. http://www.cis.es/cis/opencm/ES/1_ encuestas/estudios/ver.jsp?estudio $=1218 \&$ cuestionario $=1369$

Centro de Investigaciones Sociológicas. (2001). Situación social y política de Cataluña (XVI) (Estudio no. 2410) [Catalonia's political and social situation (XVI) (Study no. 2410)] [Data set]. Centro de Investigaciones Sociológicas. http://www.cis.es/cis/opencm/ES/1_ encuestas/estudios/ver.jsp?estudio $=1399 \&$ cuestionario $=4859 \&$ muestra $=4732$

Chernyha, L. T., \& Burg, S. L. (2012). Accounting for the effects of identity on political behavior: Descent, strength of attachment, and preferences in the regions of Spain. Comparative Political Studies, 45(6), 774-803. https://doi.org/10.1177/0010414 011427887

Clots-Figueras, I., \& Masella, P. (2013). Education, language and identity. The Economic Journal, 123(570), F332-F357. https://doi.org/10.1111/ecoj.12051

Colomines i Companys, A. (2020). The road to Catalan independence: Sovereignty, self-determination and the struggle for democracy, 2006-19. In L. Greenfeld \& Z. Wu (Eds.), Research handbook on nationalism (pp. 334-346). Edward Elgar Publishing. https:// doi.org/10.4337/9781789903447.00037

Conversi, D. (1997). The Basques, The Catalans, and Spain: Alternative routes to nationalist mobilisation (1st ed.). University of Nevada Press.

Cuadras-Morató, X., \& Rodon, T. (2019). The dog that didn't bark: On the effect of the Great Recession on the surge of secessionism. Ethnic and Racial Studies, 42(12), 2189-2208. https://doi.org/10.1080/ 01419870.2018 .1547410

Cussó, R., Garcia, L., \& Grande, I. (2018). The meaning and limitations of the subjective national identity scale: The case of Spain. Ethnopolitics, 17(2), 165-180. https://doi.org/10.1080/17449057.2017. 1360552

de Rosselló Peralta, C., Galindo Solé, M., \& Bernat i Baltrons, F. (2020). El procés de bilingüització a Catalunya en el segle $\mathrm{XX}$ a partir de testimonis orals [The process of bilingualism in Catalonia in twentieth century based on oral testimonies]. Treballs de Sociolingüística Catalana, 30, 97-111. https://doi.org/ 10.2436/20.2504.01.162

Dinas, E. (2012). Left and right in the Basque country and Catalonia: The meaning of ideology in a nationalist context. South European Society and Politics, 17(3), 467-485. https://doi.org/10.1080/13608746. 2012.701898

Dowling, A. (2014). Accounting for the turn towards secession in Catalonia. International Journal of Iberian Studies, 27(2), 219-234. https://doi.org/ 10.1386/ijis.27.2-3.219_1

Drazanova, L. (2020). Introducing the Historical Index of Ethnic Fractionalization (HIEF) dataset: Accounting for longitudinal changes in ethnic diversity. Journal of Open Humanities Data, 6(6). https://doi.org/ 10.5334/johd.16

Esteban, J., Mayoral, L., \& Ray, D. (2012). Ethnicity and conflict: Theory and facts. Science, 336(6083), 858-865. https://doi.org/10.1126/science.1222240

Fearon, J. D. (2003). Ethnic and cultural diversity by country. Journal of Economic Growth, 8(2), 195-222.

Fishman, J. A. (Ed.). (1999). Handbook of language \& ethnic identity. Oxford University Press.

Griffiths, R. D. (2015). Between dissolution and blood: How administrative lines and categories shape secessionist outcomes. International Organization, 69(3), 731-751. https://doi.org/10.1017/\$002081 8315000077

Guinjoan, M., \& Rodon, T. (2016). A scrutiny of the Linz-Moreno question. Publius: The Journal of Federalism, 46(1), 128-142. https://doi.org/10.1093/ publius/pjv031

Hierro, M. J. (2010). Canvis a curt termini en la identificació nacional a Catalunya [Short term changes in the national identification in Catalonia]. Fundació Jaume Bofill. https://fundaciobofill.cat/publicacions/ canvis-curt-termini-en-la-identificacio-nacionalcatalunya

Hierro, M. J., \& Queralt, D. (2020). The divide over independence: Explaining preferences for secession in an advanced open economy. American Journal of Political Science, 65(2). https://doi.org/10.1111/ajps. 12549

Horowitz, D. L. (1985). Ethnic groups in conflict. University of California Press.

Institut de Ciències Polítiques i Socials. (1991). Sondeig d'opinió Catalunya 1991 [Opinion poll Catalonia 1991] [Data set]. Institut de Ciències Polítiques i Socials. https://www.icps.cat/research/sondeigs-idades/sondeigs/opinion-polls-catalonia

Institut de Ciències Polítiques i Socials. (2020). Catalan public opinion poll. Integrated dataset 1991-2019 [Data set]. Institut de Ciències Polítiques i Socials. https://www.icps.cat/research/sondeigs-i-dades/ basedadesintegrada

Institut d'Estadística de Catalunya. (2018). Enquesta d'usos lingüístics de la població [Population's language uses survey]. https://www.idescat.cat/pub/ ?id=eulp

Institut d'Estadística de Catalunya. (2020). Població a 1 de gener. Per lloc de naixement (país) i sexe [Popula- 
tion on January 1st. By place of birth (country) and sex] [Data set]. Institut d'Estadística de Catalunya. https://www.idescat.cat/pub/?id=pmh\&n=7567\& lang=en

International Social Survey Program. (2015). International social survey programme: National identity III-ISSP 2013 (Study no. ZA5950; data file version 2.0.0) [Data set]. GESIS Data Archive. https:// doi.org/10.4232/1.12312

Jayet, C. (2012). The ethnic-civic dichotomy and the explanation of national self-understanding. European Journal of Sociology, 53(1), 65-95. https://doi. org/10.1017/S0003975612000033

Junqueras, O. (2012, October 8). El castellà i la República catalana [The Castillian language and the Catalan Republic]. El Periódico de Catalunya. https://www.elperiodico.cat/ca/politica/20121008/ el-castella-i-la-republica-catalana-article-dorioljunqueras-2221062

Keating, M. (1996). Nations against the state: The new politics of nationalism in Quebec, Catalonia and Scotland. Palgrave Macmillan. https://doi.org/10.1057/ 9780230374348

Kohn, H. (1944). The idea of nationalism: A study in its origins and background. Macmillan Company.

Laitin, D. D. (2000). Language conflict and violence: The straw that strengthens the camel's back. European Journal of Sociology, 41(1), 97-137. https://doi.org/ $10.1017 /$ S0003975600007906

Larsen, C. A. (2017). Revitalizing the 'civic' and 'ethnic' distinction. Perceptions of nationhood across two dimensions, 44 countries and two decades: Revitalizing the 'civic' and 'ethnic' distinction. Nations and Nationalism, 23(4), 970-993. https://doi.org/ 10.1111/nana.12345

Martínez-Herrera, E. (2002). From nation-building to building identification with political communities: Consequences of political decentralisation in Spain, the Basque Country, Catalonia and Galicia, 1978-2001. European Journal of Political Research, 41(4), 421-453. https://doi.org/10.1111/1475-6765. 00018

Maza, A., Villaverde, J., \& Hierro, M. (2019). The 2017 regional election in Catalonia: An attempt to understand the pro-independence vote. Economia Politica, 36(1), 1-18. https://doi.org/10.1007/s40888019-00143-x

McRoberts, K. (2001). Catalonia: Nation building without a state. Oxford University Press.

Miley, T. J. (2007). Against the thesis of the "civic nation": The case of Catalonia in contemporary Spain. Nationalism and Ethnic Politics, 13(1), 1-37. https://doi.org/ 10.1080/13537110601155734

Miley, T. J., \& Garvía, R. (2019). Conflict in Catalonia: A sociological approximation. Genealogy, 3(4). https://doi.org/10.3390/genealogy3040056

Moreno, L. (2006). Scotland, Catalonia, Europeanization and the 'Moreno Question.' Scottish Affairs, 54. https://doi.org/10.3366/scot.2006.0002

Muñoz, J., \& Guinjoan, M. (2013). Accounting for internal variation in nationalist mobilization: Unofficial referendums for independence in Catalonia (2009-11). Nations and Nationalism, 19(1), 44-67. https://doi. org/10.1111/nana.12006

Muñoz, J., \& Tormos, R. (2015). Economic expectations and support for secession in Catalonia: Between causality and rationalization. European Political Science Review, 7(2), 315-341. https://doi.org/ 10.1017/S1755773914000174

Oller, J. M., Satorra, A., \& Tobeña, A. (2019). Unveiling pathways for the fissure among secessionists and unionists in Catalonia: Identities, family language, and media influence. Palgrave Communications, 5(1). https://doi.org/10.1057/s41599-019-0357-z

Orriols, L., \& Rodon, T. (2016). The 2015 Catalan election: The independence bid at the polls. South European Society and Politics, 21(3), 359-381. https://doi.org/ 10.1080/13608746.2016.1191182

Rico, G., \& Jennings, M. K. (2012). The intergenerational transmission of contending place identities. Political Psychology, 33(5), 723-742. https://doi.org/ 10.1111/j.1467-9221.2012.00894.x

Rico, G., \& Liñeira, R. (2014). Bringing secessionism into the mainstream: The 2012 regional election in Catalonia. South European Society and Politics, 19(2), 257-280. https://doi.org/10.1080/13608746. 2014.910324

Rodon, T., \& Guinjoan, M. (2018). When the context matters: Identity, secession and the spatial dimension in Catalonia. Political Geography, 63, 75-87. https:// doi.org/10.1016/j.polgeo.2018.01.004

Sanjaume-Calvet, M., \& Riera-Gil, E. (2020). Languages, secessionism and party competition in Catalonia: A case of de-ethnicising outbidding? Party Politics. Advance online publication. https://doi.org/ 10.1177/1354068820960382

Sendra, M. (2016). Media articles about the controversy on the official languages in Catalonia, by date. Les Ilengües a la Catalunya Independent. http:// llenguescatalunyaindependent.weebly.com

Serrano, I. (2013). Just a matter of identity? Support for independence in Catalonia. Regional \& Federal Studies, 23(5), 523-545. https://doi.org/10.1080/ 13597566.2013.775945

Smith, A. D. (1991). National identity. University of Nevada Press.

Sorens, J. (2005). The cross-sectional determinants of secessionism in advanced democracies. Comparative Political Studies, 38(3), 304-326. https://doi.org/ 10.1177/0010414004272538

Tamir, Y. (2019). Not so civic: Is there a difference between ethnic and civic nationalism? Annual Review of Political Science, 22(1), 419-434. https://doi.org/ 10.1146/annurev-polisci-022018-024059

Tobeña, A. (2017). Secessionist urges in Catalonia: Media indoctrination and social pressure effects. Psychol- 
ogy, 8(01), 77-96. https://doi.org/10.4236/psych. 2017.81006

Tormos, R., Muñoz, J., \& Hierro, M. J. (2015). Identificació nacional: Causa o conseqüència? Els efectes del debat sobre la independència en la identitat dels catalans [National identification: Cause or consequence? The effects of the debate on independence in Catalans' identity] (Working Paper). Centre d'Estudis d'Opinió. https://ceo.gencat.cat/web/.content/30_ estudis/03_publicacions/Papers_treball/2015_05_ 05_papers_treball_idnacweb.pdf

Verge, T., Guinjoan, M., \& Rodon, T. (2015). Risk aversion, gender, and constitutional change. Politics \& Gender, 11(03), 499-521. https://doi.org/10.1017/ S1743923X15000264

Yacobson, A. (2013). State, national identity, ethnicity: Normative and constitutional aspects. In A. Gat \& A. Yacobson (Eds.), Nations: The long history and deep roots of political ethnicity and nationalism (pp. 328-379). Cambridge University Press.

\section{About the Author}

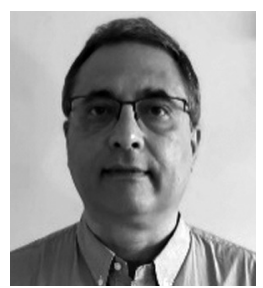

Jordi Argelaguet is a senior lecturer in the Department of Political Science and Public Law at the Universitat Autònoma de Barcelona, where he teaches undergraduate courses in political science, political parties, and Spanish politics. His main fields of research are nationalism, political parties, and language policy. Between 2011 and 2021, he was director of the Centre for Opinion Studies of the Government of Catalonia. 